\title{
Impacts of endocrine disruptors on reproductive health in the era of increased personal care and beauty products usage
}

\author{
Moses Asori ${ }^{*}{ }^{*}$, Julius Odei ${ }^{1}$, Daniel Katey ${ }^{1}$, Truus Apoanaba Abuosi ${ }^{2}$ and Razak M. Gyasi ${ }^{3}$
}

\begin{abstract}
Background: Endocrine disruptors originate from multiple sources making their health impacts enormously complex. This study systematically synthesizes the sources, exposure, and effects of personal care products on reproductive health.

Main body: The PRISMA and Meta-Analyses frameworks were used to review and present integrated evidence. The literature search was undertaken in PubMed, Google Scholar, and Scopus. All studies that focused on the sources, exposure pathways, and reproductive health impact of endocrine disruptors were included in the final review. Although the review included articles published from 2000 to 2021, most studies were conducted between the years 2010 and 2020. There was great variability in terms of studies conducted in individual countries, of which $34.4 \%$ were published in the USA. The review found that endocrine disruptors abound in the environment and their impact on females and males' reproduction are profound. Phthalates, Bisphenol A, MXC, and Dioxins were widely studied EDCs as determiner of reproductive health. Crucially, the human body concentration of these EDCs varies between people of diverse backgrounds.

Conclusion: While the bodily concentration of these EDCs is higher, it varies greatly among different groups of people. Respective governments and NGOs should provide the needed funding for research on personal care products and EDCs. Moreover, individual and spatial heterogeneity should be considered in the risk assessment of these chemicals.
\end{abstract}

Keywords: Endocrine disruptive chemicals, Personal care products, Reproductive health, Exposure pathways

\section{Background}

Personal care products including facial and hair creams, hand soaps, and skin lightening products are major sources of endocrine disruptive chemicals (EDCs) such as parabens, triclosan, and phthalates. In the past few decades, the number of personal care products production and usage has increased significantly (Wang et al. 2021; Garlantézec et al. 2013). Young and sexually active people between the ages of 18 and 30 years around the world are

\footnotetext{
*Correspondence: asorimoses00@gmail.com

1 Department of Geography and Rural Development, Kwame Nkrumah

University of Science and Technology, Kumasi, Ghana

Full list of author information is available at the end of the article
}

increasingly using pharmaceutical, cosmetic, and other related personal care products for reasons including maintaining sexual drive, sexual outlook, and mood-stabilizing (Hardon et al. 2013). Yet, health science researchers largely ignore the assessment of post-consumption risks and consequences (Hardon et al. 2013; Wang et al. 2021). Given that most of these chemicals easily permeate every facet of our lives, their health impacts remain profound (Bellavia et al. 2019; Dutta et al. 2020; Meeker et al. 2011; Rattan and Flaws 2019; Zota and Shamasunder 2017; Dodge et al. 2015; Li et al. 2019).

Current estimates show that about 18 million pounds of phthalates are manufactured every year, for which the majority of them are plasticizers such as polyvinyl 
chlorides (PVC), used in making plastic products (Rat$\tan$ and Flaws 2019). However, they can easily find their way into various parts of the human biological system including the livers and kidney (Costa et al. 2014; Meeker et al. 2011; Rattan and Flaws 2019). Currently, about 80\% of personal care products such as shampoos, hand soaps, body lotion, and makeup contain parabens, triclosan, and other EDCs. It is not surprising that $75-100 \%$ of people around the world are exposed to various EDCs-induced health risks (Rattan and Flaws 2019). Although these synthetic biochemicals are used mostly as a safety mechanism in products such as anti-microbial and preservatives in personal care products, foods, and drinks, there is a permissible concentration level set by Consumer Ingredient Review (CIR), beyond which consequences becomes apparent (Aydemir et al. 2020).

The impact of EDCs is far-reaching, intersecting various biochemical, and physical aspects of human lives including obesity, diabetes, ovarian damage, sperm DNA damage, etc. (Pirard et al. 2018; Gravel et al. 2020; Schrager and Potter 2004; Wang et al. 2021). These disruptors increasingly affect the estrogen-dependent signaling, which can potentially change the normal beta cell operation. Recently, attempts have been made to undertake a comprehensive evaluation of the arrays of phthalates and parabens and how they affect the sexual health of males and females. It is now well understood that these chemicals can impact reproduction ability through low sperm count, prostate cancer, and ovarian damage (Priskorn et al. 2018). One study found that phthalates are responsible for ovary dysfunction, which can disrupt folliculogenesis in females. And as noted by Costa et al. (2014) and Hannon and Flaws (2015), any interruption in the folliculogenesis process as a result of ovarian malfunctioning can lead to infertility and premature ovarian failures. Many endocrine disruptive chemicals abound in our environment considering the multitude of market-based consumables such as personal care products containing these chemicals. Evidence in terms of their sources, exposure pathways, impacts, and differential impact among people of different races, nationalities, or economic statuses is nevertheless disparate. In order to provide evidence-based medical practice and health intervention, there is a need to improve understanding of these mechanisms. However, a comprehensive review on this topic is lacking. The current study seeks to synthesize the sources, exposure, and effects of personal care products on reproductive health.

\section{Main text}

The PRISMA guideline was followed to report this review (Moher et al. 2009). A systematic literature search was undertaken in diverse research databases of PubMed and Scopus. These databases contain up-to-date relevant papers crucial to the current study. Also, manual searches were conducted in Google scholar to identify other relevant papers that may not be stored in the designated databases. Search terms such as "endocrine disruptors" OR "endocrine disruptive chemicals" AND "personal care products" in conjunction with "reproductive health" AND "sources" AND "exposure pathways" were used to get relevant papers. The classic PRISMA flowchart is presented in Fig. 1.

All papers published between 1953 and 2021 that considered endocrine disruptors sources, pathways of exposure, personal care products, and endocrine disruptors' impact on sexual health and the aging process were included in the final review. However, papers that considered available technologies for the removal of these disruptors from the various environmental compartments were not considered in the current review since that was not the focus of the study.

To ensure reliability and reduce biases, all papers were downloaded by two independent researchers following the priori protocols such as screening through topics to abstracts and final download based on the PRISMA framework (Fig. 1). We considered journal papers including primary studies, opinions, commentaries, and conference papers. A total of 753 records were extracted initially by two researchers, independently. 123 were duplicates and were therefore removed leaving 630. We incrementally added 15 papers which totaled 645 papers. Further, 505 papers were removed since they were outside the conceptual scope of our review. By careful examination of the 140 remaining articles based on quality appraisals, we further removed 25 papers; the remaining 115 studies were considered worthy of review per the themes for the review.

All articles downloaded and included in the final review were in English. Even though typically, papers were downloaded from 2000 to 2021, most studies were conducted between the years 2010 and 2020 (see Fig. 2). All the papers were organized and analyzed based on the themes (sources and exposure pathways of EDCs, impact of EDCs reproductive health, impact of EDCs on aging and puberty development). We also used phthalates as a case study to examine how similar or heterogeneous their concentration in urine was, as a way of understanding differential exposure. Specifically, one-way ANOVA was used to test the statistical difference between five metabolites of phthalates urine concentration in women conducted in various countries based on selected articles.

\section{Description of the studies}

A total of 753 records were extracted initially by two researchers, independently. 123 were duplicates and 


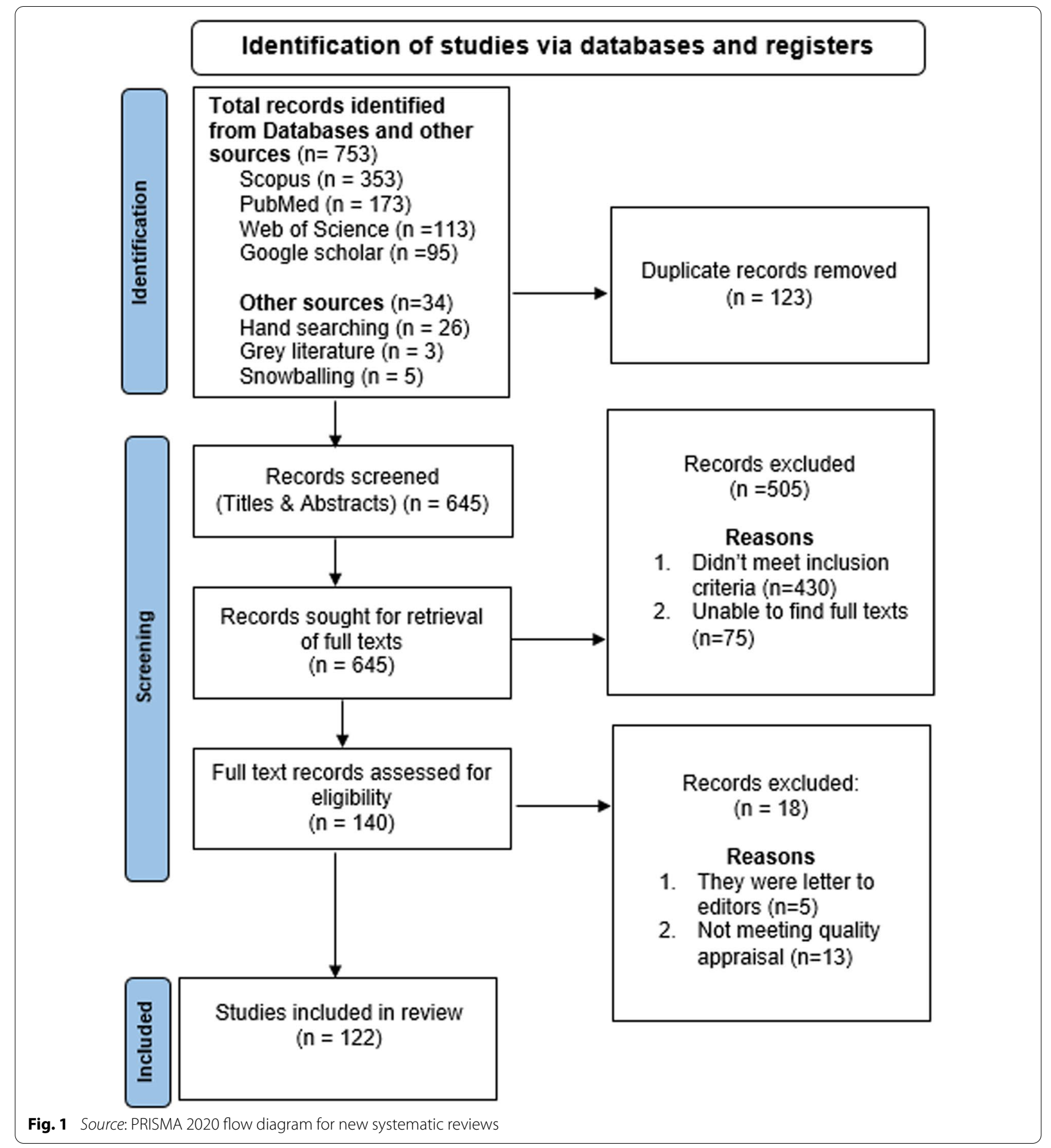

were therefore removed leaving 630. We incrementally added 15 papers which totaled 645 papers. Further, 505 papers were removed since they were outside the conceptual scope of our review. By careful examination of the 140 remaining articles based on quality appraisals, we further removed 18 papers; remaining 122 studies which were considered worthy of review per the themes for the review. We found that there was a great variability in terms of studies conducted in individual countries, with almost half (34.4\%) of the studies coming from the USA (Fig. 3) 


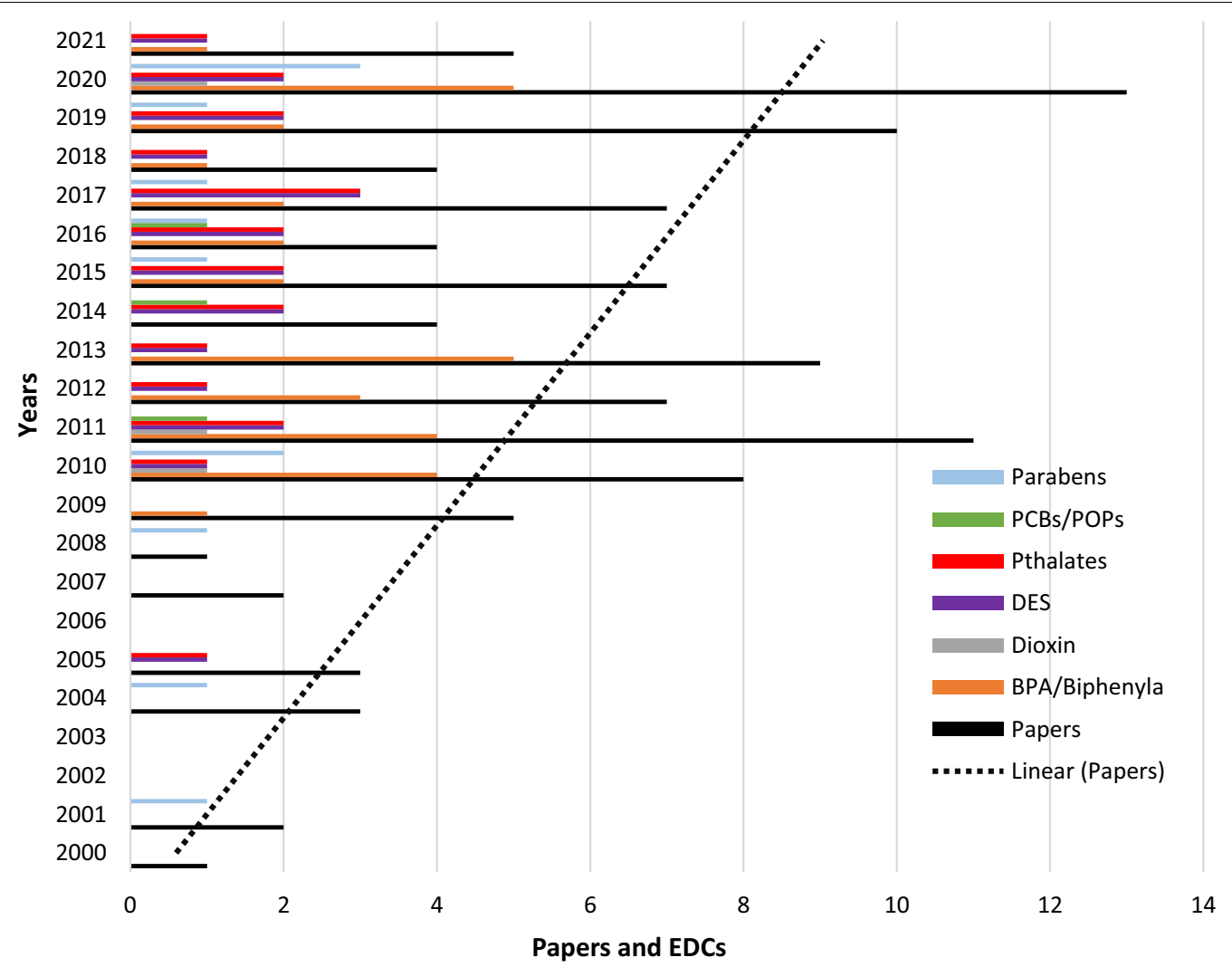

Fig. 2 Temporal trends of papers published and chemicals studied

More studies accorded attention to females than males. Based on chemicals mostly studied, we found that most of the studies focused on Phenols (especially Bisphenol A), Methoxychlor, Dioxins, Phthalates, and DES. Studies involving these chemicals too have increased over the last ten years as shown in Fig. 2. This indicates that these EDCs have attracted the attention of scientific communities significantly, suggestive of their immense impact on human and animal reproductive health. For studies involving human beings, the sample size varied greatly, from 40 to 6,386 people.

\section{Various endocrine disruptors: sources and pathways of exposure}

Man-made chemicals are now emerging organic chemicals, some of which disrupt the normal operation of the endocrine system (Hartmann et al. 2015; Patisaul and Adewale 2009). They are widespread and used for diverse purposes: beautification, self-grooming to sex enhancement and even building construction (Rattan and Flaws 2019; Wang et al. 2019). As a result, they originate from multiple sources including personal care products (Iribarne-Durán et al. 2020; Meeker et al. 2011; Petersen et al. 2020), as shown in Table 1, for example. Due to their widespread nature in the environment, their exposure pathways are complex (Babalola et al. 2020; Oyugi et al. 2021). For example, most of the parabens, BP-3, and the metabolites of phthalates were found in 82.8 to $100 \%$ of the urine samples of 261 Belgian populations (Dewalque et al. 2014). Even though it was earlier thought that the dose-response curve was monotonic in nature, later works proved that the curve is actually non-monotonic, and thus, the dose-response curve can be in different shapes: sigmoid, U-shaped, or inverted-U-shaped curves (Rattan and Flaws 2019). So, even little doses can have serious effects on the human system. It is therefore imperative that their sources and different pathways of exposure and impact be assessed for adequate response measures. Since most of these chemicals have weaker molecular bonding, they are easily released into food, drinks, water, soils, and even the air, making it easier for humans to ingest, dermally contact or inhale them (Dutta et al. 2020; Patisaul and Adewale 2009).

For example, Bisphenol A. (BPA) is often used as epoxy resins in aluminum cans for food or beverage storage. However, due to weaker molecular bounds, they detach themselves after polymerization and diffuse into foods (Rattan and Flaws 2019). Similarly, metabolites of 


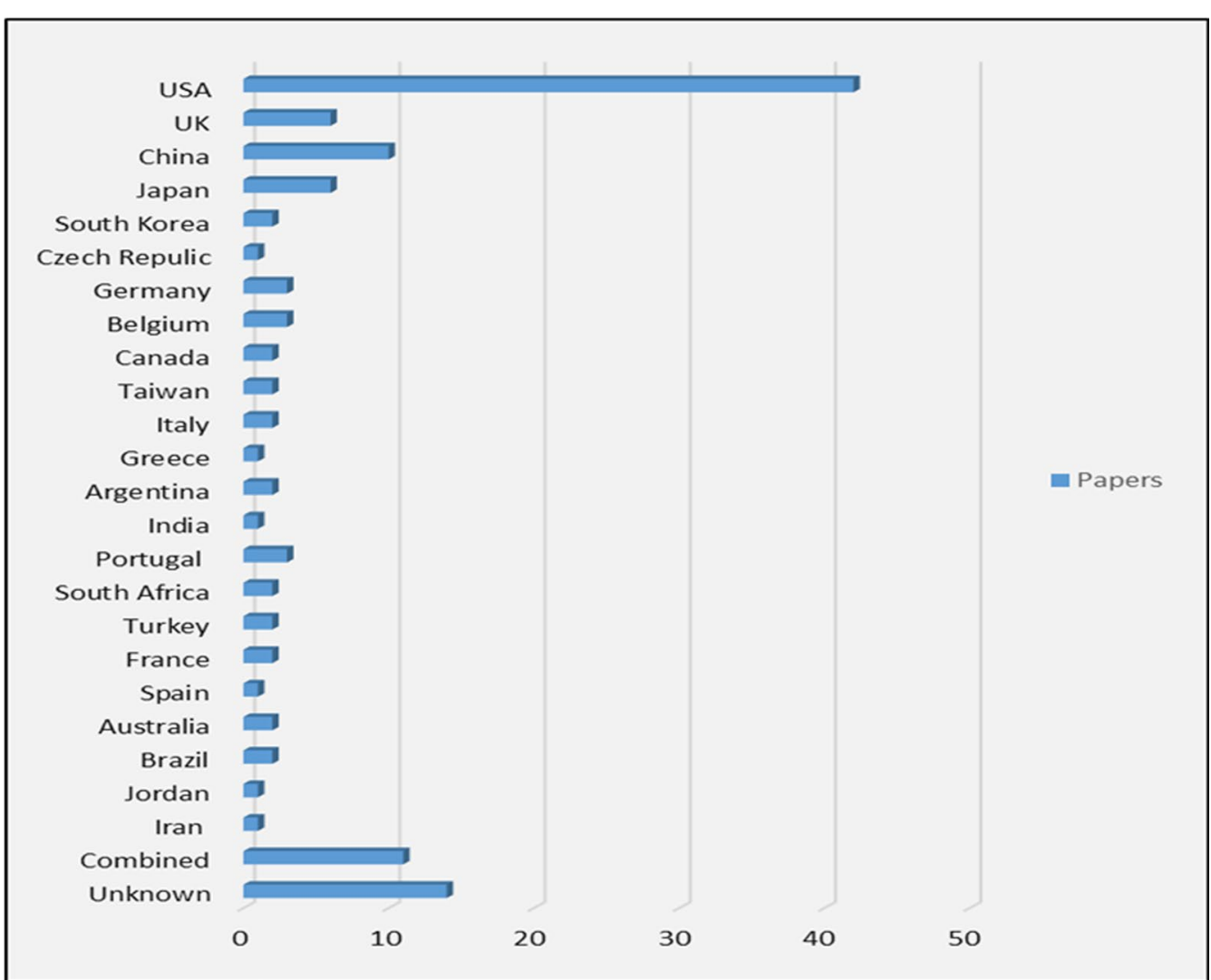

Fig. 3 Distribution of papers found for individual countries

phthalates such as polyvinyl chloride (PVC) are used as plasticizers and in the manufacturing of water pipelines and personal care products. PVC molecules can also leach into the water and foods and finally be ingested by people, thereby increasing their health risk (MínguezAlarcón et al. 2019; Nassan et al. 2017).

Other studies also show that the use of Dicholorodiethyltricholoroethene (DDT) as pesticides constitutes an exposure pathway through contamination of fishes and waterbodies (Woldetsadik et al. 2021). As a result, through direct ingestion of such contaminated fishes, these toxins find their way to the human system (BuahKwofie and Humphries 2021). Even though Methoxychlor (MXC) was introduced to replace DDT, its use has also been criticized as being toxic (Rattan and Flaw 2019). Some studies have shown that, in some countries, the concentration of DDT in the breast milk of women has increased despite increasing evidence of its destructive impact. For instance, a study conducted in Mozambique found that the concentration of DDT and its metabolite (DDE) in the breast milk of pregnant women increased between 2002 and 2006, and that the concentration also varied markedly between women, reaching as high as $5100 \mathrm{ng} / \mathrm{g}$ lipid in some women (Manaca et al.
2011). This shows how widespread these chemicals are, despite several attempts to ban them in many countries. It even appears that most countries have made little to no effort to ban them. Another study that investigated children exposure to phthalates and non-phthalate plasticizers in homes found that dusts and hand wipes were significant sources of monomethyl phthalate (MEP) and mono-n-butyl phthalate (MnBP), metabolites of DEP and DnBP, and that children who lived in homes with $100 \%$ vinyl flooring were significantly exposed to monobenzyl phthalate (Hammel et al. 2019).

\section{Males exposure to EDCs and reproductive health impact}

Given that men are exposed to several endocrine disruptive chemicals (Table 1) with severe reproductive health implications, it has now become a global concern, especially with the recent discovery that poor fertility rate and low sperm count among men over the world are exacerbating (Inhorn and Patrizio 2015). In fact, the sociocultural, economic, bio-social, and anthropological consequences of men not being able to father children are far-reaching, and it may be a significant threat to procreation necessary to ensure human existence. As a result, the American Congress of Obstetrics and Gynaecology 


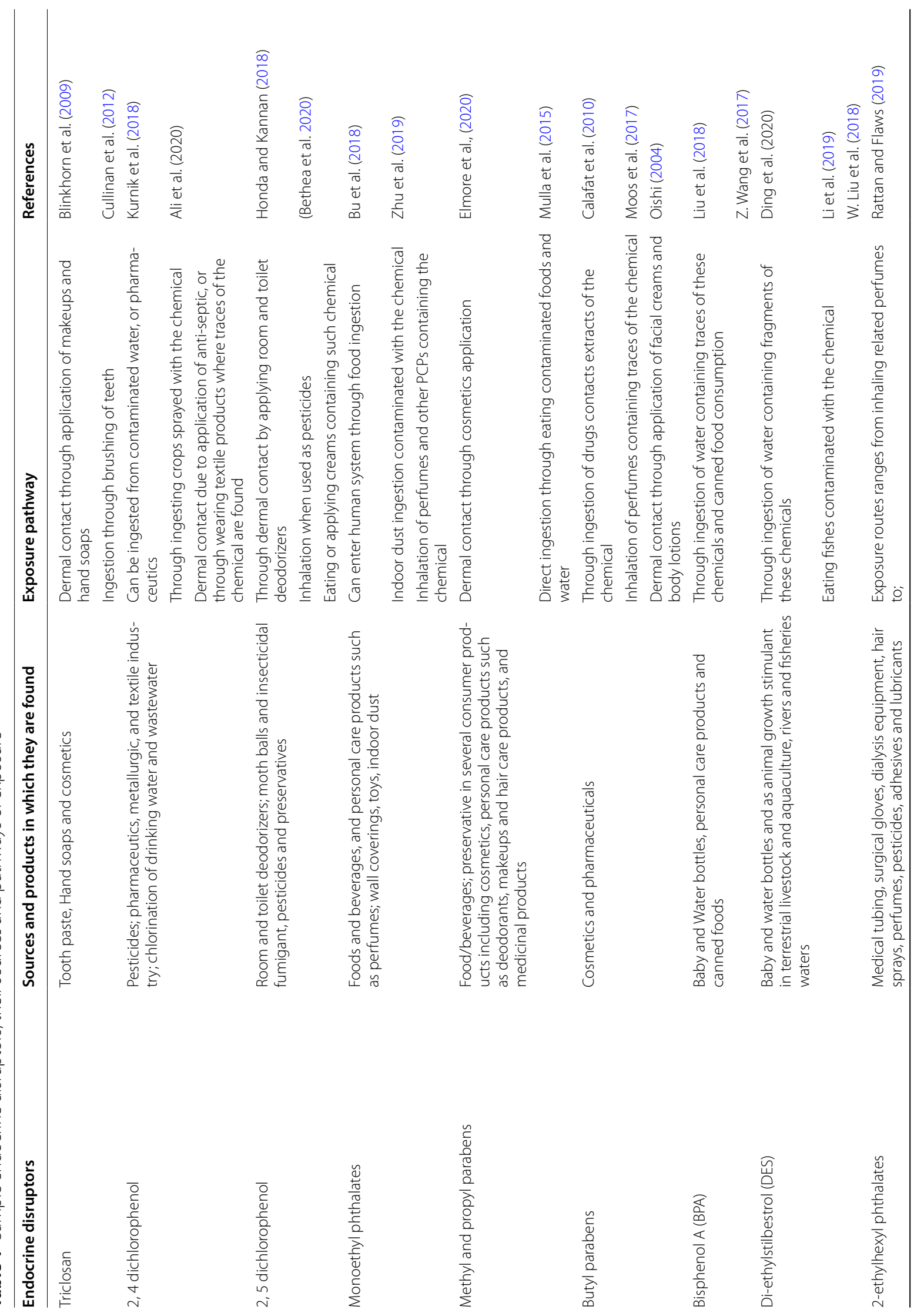




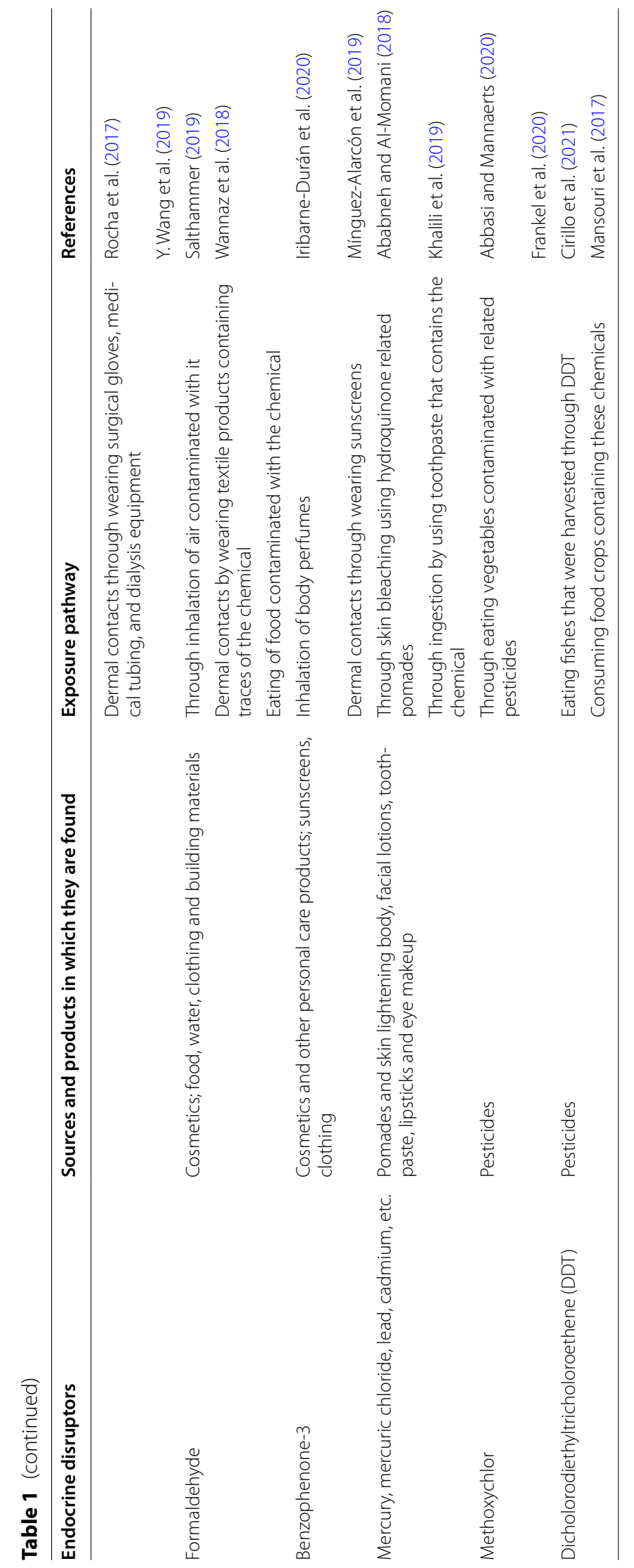


(ACOG) and Internal Federation on Obstetrics and Gynaecology (FIGO) suggest that healthcare professionals should examine detailed population risk factors to pattern-use of PCPs and disproportionate exposure burden among different patients groups including men (Di Renzo et al. 2015).

\section{EDC impact on sperm and testicular health}

Sperm health is central to fertility and childbearing. However, a number of EDCs have been noted to compromise the quality of certain parameters of the sperm. Meeker et al. (2011) discovered that butyl paraben (BP) and Bisphenol A (BPA) were significantly related to increased sperm DNA damage $(p=0.003)$. This study's finding corroborated earlier discovery that increased concentration in Butyl and Propyl parabens is linked to severe damages in spermatogenesis, prostate cancer, and seminal vesicular challenges (Kang et al. 2002; Oishi 2001, 2004). A major factor of sperm DNA damage is oxidative stress. These oxidative stress-induced chemicals such as butyl parabens are responsible for sperm cell annihilation. For example, one study reported a significant linkage between EDCs concentration in men and higher levels of cryptorchidism, hypospadias, and cancer of the testis, which are found to impact childbearing potential (Nassan et al. 2017). One controlled animal study showed that the male mice and rats had reduced epididymal sperm density when they were exposed to benzophenone-3 indicating how destructive and severe benzo-phenone- 3 exposure is to the sexual or reproductive health of men. Sperm quality reduction has also been noted in some men who were exposed to BPA. Pesticides such as DDT and its metabolites are also associated with sperm viability reduction. An animal study showed that higher exposure to dichlorodiphenyldichloroethylene ( $p$, p'-DDE) in vitro was responsible for decreased sperm viability, and interestingly, biomimicry of the female reproductive tract and even the overstimulation of CatSper (Tavares et al. 2013). The CatSper is the calcium $\left(\mathrm{Ca}^{2+}\right)$ pathway that is crucial for sperm capacitation and sperm motility (Yuan et al. 2022). Other biomarkers of spermatogenesis such as alkaline phosphatase, lactate dehydrogenase, and acid phosphates have all been altered in the testes of rats (Sharma et al. 2020). 2, 3, 7, 8-tetrachlorodbenzo-p-dioxin (TCDD) has also been noted to impair steroidogenesis by decreasing the expression of biomarkers such as StAR protein, 17-3- $\beta-$ HSD, and 3$\beta$-HSD, including disruption of the testicular histology (Mai et al. 2020). One meta-analysis concluded that anogenital distance (AGD) was linked to testicular anomalies which are indicative of how EDCs affect reproduction in men since it is an important marker of prenatal androgen activities (Street et al. 2018). A similar study found that first-trimester phthalates exposure was responsible for shorter AGD (Swan et al. 2015) even though some studies found no association. Exposure to di-pentyl-phthalates has also been found to reduce AGD and interrupt male differentiation (Hannas et al. 2011). Furthermore, a meta-analysis involving 33 studies showed that in particular, the impact of DDE was profound in causing cryptorchidism, hypospadias, and testicular cancer (Bonde et al. 2017).

\section{Sperm count and sperm production impacts of EDCs}

An animal study that examined the impact of maternal exposure to butyl-paraben on F-1 offspring sperm count in Japan found that the offspring experienced reduced testes, seminal vesicles, sperm count, and prostate glands (Kang et al. 2002). Similarly, another animal study conducted in Japan found that exposure to Butyl-paraben led to a significant reduction in the relative weights of sperm reserve. The study also found that daily sperm production declined significantly (Oishi 2001). Contrary, methyl, and ethyl parabens were found to have no impact on the secretion of sex hormones and male reproductive function (Oishi 2004). More studies are however needed to confirm this. Common metabolites of phthalates such as di (2-ethylhexyl) phthalate (DEHP) have also been associated with a reduction in sperm reserve and production. For instance, a study that studied mice exposure to DEHP found that these mice had a 30\% decrease in their daily sperm production, a $70 \%$ reduction in epididymal sperm reserve, and a $20 \%$ decrease in the viability of the sperm (Fiandanese et al. 2016). A similar study has confirmed that exposure to Butyl benzyl phthalates resulted in decreased sperm count, reduced seminiferous tubule on the histology, and retarded preputial penis separation in rats (Aso et al. 2005).

A study involving 191 men found that $93 \%$ of them had BPA in their semen, and that resulted in a significant reduction in sperm count, volume, and motility (Vitku et al. 2016). However, a study of 364 men found no significant correlation between sperm count and BPA concentration, even though the direction of association was negative (Hu et al. 2017). Such disparity in findings y may be a result of different confounders that may have moderated such relationships. Metabolites of dioxin such as 2, 3, 7, 8-tetrachlorodbenzo-p-dioxin (TCDD) are a common eco-toxin that has been studied among a couple of animals (Foster et al. 2010). The TCDD has the ability to activate and bind the aryl hydrocarbon receptor (AhR) which is a key ligand transcription factor which is found in many human tissues (Foster et al. 2010). In one animal study, rats in their gestation period were exposed to TCDD, and results showed that their offspring had their ejaculated sperm count reduced substantially, without a 
decline in their serum testosterone and the level of their androgen receptors (Foster et al., 2010). Even though the mechanisms responsible for the epididymal sperm count reduction were unknown, the impact of the AhR activation on activities of the epididymis was a potential suspect (Hutin et al. 2021). A study also indicated that male mice exposure to TCDD resulted in a significant reduction in their sperm reserve and sperm motility (Mai et al. 2020). A meta-analysis involving 33 studies involving the exposure of uterus to EDCs revealed that dichlorodiphenyldichloroethylene $(1,1$ ' DDE) was also a significant factor in the reduction of sperm count in offspring (Bonde et al. 2017).

\section{EDCs impact on Sperm fertility}

The ability of the sperm to fertilize is central in reproduction (Maffini et al. 2006; Meeker et al. 2011; Publicover et al. 2008). However, some EDCs have been noted to tamper with the ability of sperm in fertilization. Even though studies on this subject are scarce, we found two studies that provided consistent results. In one study, mice were administered with DHEP, DEP, DMP, and BPA. Results show that DEP and DMP, which are common in personal care products and cosmetics, respectively, had no impact on sperm fertility and even on the formation of the blastocyst (Khasin et al. 2020). BPA was found to have a mild impact on blastocyst formation and the development of the embryo. DHEP, which is common in construction materials and in numerous polyvinyl chloride products, was found to have a severe impact on blastocyst formation, but the impact varied with the amount of exposure (Khasin et al. 2020). While at $1 \mu \mathrm{M}$ dose, the sperm maintain its fertilizing ability, at $2 \mu \mathrm{M}$ dose, there was a substantial decline $(74.95 ; \mathrm{SD}=5.459 \%$ in control vs. $47.68 ; \mathrm{SD}=9.68 \%$ in $2 \mu \mathrm{M}$ ), and even at $10 \mu \mathrm{M}$ dose, no blastocyst formation was found. The study further demonstrated that DHEP was able to impair the acrosome reaction and increased the production of ROS (Khasin et al. 2020).

Crucially, the human sperm cell must be regulated accurately to allow fertilization to take place (Suhaiman et al. 2021). The progesterone released by the cumulus cell is known to cause $\mathrm{Ca}^{2+}$ to induce the human sperm cell through the CatSper $\mathrm{Ca}^{2+}$ pathway, thereby moderating the activities of the sperm cell (Publicover et al. 2008; Stephen et al. 2007). However, a number of UV filters that are known endocrine disruptors are found to induce the influx of $\mathrm{Ca}^{2+}$ through the CatSper, thereby mimicking the effect of the progesterone on sperm functioning (Rehfeld et al. 2018). One study examined the impact of 29 UV filters (commonly found in sunscreens) on sperm functioning and fertility. It was found that UV filters that mimic the progesterone effect on $\mathrm{Ca}^{2+}$ in human cells can equally mimic the activities of the progesterone on acrosome reaction and sperm penetration (Rehfeld et al. 2018). They concluded that exposure to these filters has the potential to impair sperm fertility by interrupting the functions of the sperm such as causing premature acrosome reactions. A study from Japan found that male mice exposed to $400 \mathrm{mg} / \mathrm{kg}$ butyl benzyl phthalates led to a significant reduction in their fertility index resulting from a reduction in spermatozoid qualities and volume (Aso et al. 2005). Further studies are needed to provide more evidence.

\section{Exposure assessment of EDCs among women}

Considering the widespread use of PCPs among women for various reasons, a number of experiential studies have attempted to quantify the extent of women's exposure to EDCs. Measuring exposures to EDCs is central for risk assessment and to safeguarding people against lethal biochemical consequences. One medical case study in the USA showed that Mexican-American women's mercury blood level of $15 \mu \mathrm{g} / \mathrm{L}$ (about 3 times higher than CDC safety threshold) was associated with face creams use made of $>20,000 \mathrm{ppm}$ of inorganic mercury (even though $>1 \mathrm{ppm}$ is known to be lethal) (Zota and Shamasunder 2017). Methylparaben (MP), ethylparaben $(\mathrm{EP})$, propylparaben (PP), and butylparaben (BP) have recently been identified in greater quantities in urine samples collected as part of the long-term US national survey of exposure to eco-toxins (Calafat et al. 2010). The use of these personal care products such as beautification creams sometimes begins at a very tender age usually 4 to 8 years among African-Americans children and typically gets heightened between 18 and 34 years (Wang et al. 2019; Zota and Shamasunder 2017).

Figure 4 shows that the spatial distribution of the five metabolites of phthalates, for example, varies from country to country, and also between individual chemicals. Particularly there exist marked dissimilarities in terms of reported urine concentration of these toxins, except for methyl ethyl phthalates (MEPs) which show dominance across many nations. Most of the studies used for the plot in Fig. 4 ranged from the years 2013 to 2017, showing that, lately such studies are gaining recognition in many countries. From f-test analysis, we found statistically significant differences between reported urine concentrations of the various phthalates in women $(F=10.76$; $p=0.001$ ) suggesting that even among women, exposure risk levels may be different.

These differences may be as a result of variant patterns in the use of personal care products, quality of the physical environment, or even socioeconomic condition of the people concerned (Lang et al. 2016; Zota and Shamasunder 2017). For example, three 3 studies 


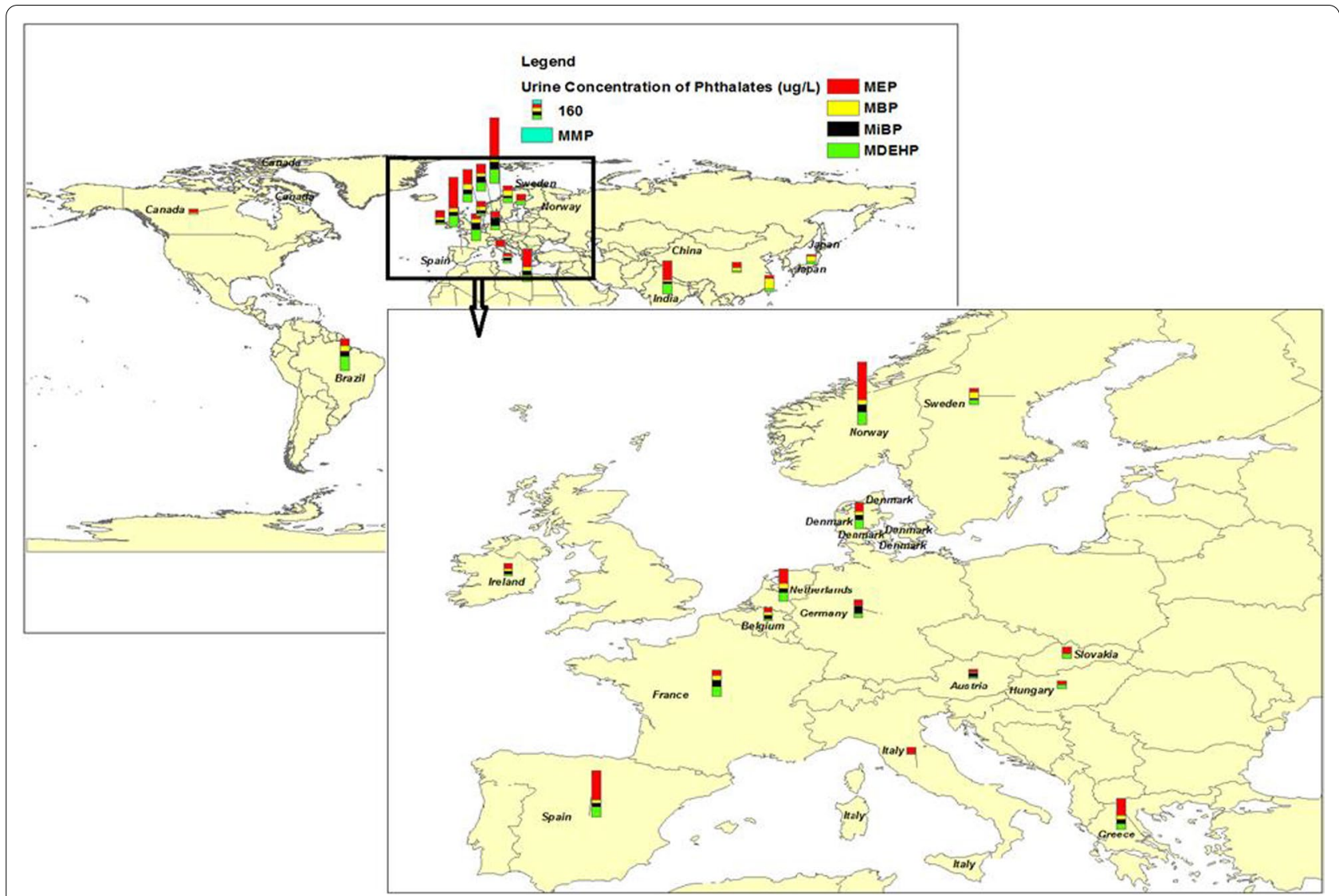

Fig. 4 A charted map showing the global distribution of women urine concentration of various metabolites of phthalates (MBP $=$ Methyl butyl paraben; MiBP = Methyl-iso-butyl paraben; MMP = Mono-methyl phthalate; MDEHP is a sum total of five metabolites including MEHP (mono-ethyl-hexyl phthalate), MEHHP (mono-(2-ethyl-5-oxy hexyl) phthalate)), MECPP(mono-(2-ethyl carboxy-pentyl)phthalate), and MCMHP (mono-(2-carboxy-methyl-hexyl) phthalate)). For detailed reference to the data for the plot (Wang et al. 2019)

reported that it is more likely for an African or AfricanAmerican woman to use a higher amount of whitening or hair straightening creams than a white woman with lighter skin (Nyoni-Kachambwa et al. 2021; Wang et al. 2021; Zota and Shamasunder 2017). A study conducted among black women in America also showed that exposure to phenols, parabens, and triclocarban was prevalent due to the higher use of PCPs (Bethea et al. 2020). The study also found a significant association between education level and the amount of PCP and exposure to the studied EDCs (Bethea et al. 2020). Similarly, another study in the USA showed that black women had higher cumulative EDCs exposure than white women indicating racial disparity in EDCs risk and exposure levels (Varshavsky et al. 2016). It is therefore crucial that different studies be conducted in socioculturally diverse environments to determine and evaluate the association between race and socio-demographic uniqueness and EDCs exposure levels.

\section{Reproductive Health impact of EDCs among women}

Given that multitudes of these PCPs house arrays of chemicals which disrupt the endocrine and reproductive systems (Bellavia et al. 2019; Patisaul and Adewale 2009; West et al. 2008), the profuse illnesses currently affecting millions of women can partly be attributed to the impact of these EDCs. EDCs can also block certain hormonally controlled functions responsible for the interaction between human anatomical elements and their immediate physical environment (Rodríguez and Sanchez 2010), which consequently affects human homeostasis and reproduction (Dutta et al. 2020; Hannon and Flaws 2015; Neff and Flaws 2021; Buah-Kwofie and Humphries 2021). In the subsequent sections, we discuss how these EDCs impact; uterus structure, uterine myomas, vaginal health, and infertility among women. 


\section{The uterine structure}

The uterus of females is essentially made up of two major parts; the body which consists of the endometrium, and the caudal end; both of which are susceptible to dynamics of the hormones, during early developmental stages. Even though how EDCs influence the overall structure of the uterus is largely unclear, few animal studies report of EDCs induced abnormalities within the uterus. For example, in two animal studies (Signorile et al. 2010, 2012), Balb-c-adult female rats in their gestational and neonatal periods were exposed to BPA to understand how it affects their uterus structure. It was found that within the adipose tissue, next to the genital tract of these rats, there was a development of endometrial glands and stroma suggestive of uterine structure alteration. Also, one Australian study found that women who were exposed to mono (carboxy-isooctyl) phthalates experienced an increment of their uterine volume. A couple of studies conducted in the $1950 \mathrm{~s}$ and $70 \mathrm{~s}$ demonstrated that women who were treated with DES to avert miscarriages led to significant anomalies within the uterine structure of their daughters later on (Dieckmann et al. 1953; Herbst 1976; Herbst et al. 1971). A few studies conducted later on found evidence consistent with earlier findings (Harris and Waring 2012; Troisi et al. 2013). For example, two animal studies conducted in 2011 found that female rats and hamsters who were exposed to DES developed endometrial hyperplasia, and that they were more likely to experience adenocarcinoma within their endometrium, and structural changes within their uterus (Alwis et al. 2011; Yoshida et al. 2011). A study conducted by Su et al. (2012) found that 33 young girls who were given dioxin and polychlorinated aromatic by-products of biphenyls experienced significant anomalies within their uterine structure. All these anomalies potentially inhibit conception among females.

\section{Uterine myomas/fibromas}

Evidence also shows that reproductive health challenges such as uterine myomas which are hormone-dependent affect $70-80 \%$ of women throughout their lifetime. These uterine fibroids are responsible for negative pregnancy outcomes such as miscarriages. Several kinds of myomas and nodular tumors are associated with estradiol and progesterone receptors found within the myometrium. The endometrium and myometrium cells are typically regulated by granulosa cells of the ovarian follicles produced by the estradiol. These endometrium and myometrium cells are regulated through activation of their alpha and beta-cell receptors. However, the binding of the estradiol with its receptors can create a number of bioevents, typically within the nucleus of the cell by bringing in essential proteins to the cellular reproduction.
During ovulation, the progesterone produced by the corpus luteum binds to both the alpha and beta receptors. Research shows that these alpha and beta receptors are responsible for the expression of multiple genes which create diverse cellular responses. Though we did not find many studies that reported a significant association between EDCs and their ability to cause the development of fibromas within the uterus as a result of their attachment with these receptors, two case-control studies (Shen et al. 2013; Zhou et al. 2013) from China found an association between uterine myomas development and BPA, nonylphenol and octylphenol concentration in women. Some studies have also found an association between uterine myomas and certain metabolites of phthalates (Weuve et al. 2010). For instance, a National Health and Nutrition Examination Survey (NHANES) study conducted in 2010 found that bodily contamination of mono-benzyl phthalates was a risk factor for increased cases of myomas among the 1227 women studied (Weuve et al. 2010). On the contrary, other metabolites such as MEHP (mono-(2-ethylhexyl) phthalate), MEHHP (mono(2-ethyl-5-hydrohexyl) phthalate), and EOP (mono(2-ethyl-oxohexyl) phthalate) were negatively associated with the onset of uterine myomas (Weuve et al. 2010).

Even though prenatal exposures to EDCs and uterine myomas/fibromas are scarce, the few ones we found provided consistent results. A study that included 11,831 women with a follow-up of over 20 years found that generally, women who were exposed to DES during their gestational periods increased their risk of fibroma by $13 \%$ whereas those within the first trimester of their pregnancy increased their risk by $21 \%$ relative to unexposed women, indicating that uterine fibroid risk may vary between pregnant women in different gestational time points, even if they are exposed to the same amount of DES (Baird and Newbold 2005; Mahalingaiah et al. 2014). Furthermore, a uterine fibroma study conducted in Washington DC involving 1364 women found that Caucasian women were more likely than other racial groups to experience uterine fibroid $(\mathrm{OR}=2.4)$. A sister study conducted 7 years later (2012) among 3534 AfricanAmerican women showed that women with maternal and gestational diabetes as well as those pregnant with monozygotic twins had odd ratios of 2.02, 1.54, and 1.94, respectively, of developing uterine fibroid when exposed to DES (D'Aloisio et al. 2012), also suggestive that maternal diabetes may increase the risk of developing uterine fibromas when exposed to a particular endocrine disruptor.

\section{Vaginal health and fertility}

A couple of studies conducted in the 1950s, $70 \mathrm{~s}$, and in the 2000s (Dieckmann et al. 1953; Herbst 1976; Herbst 
et al. 1971; Harris and Waring 2012; Troisi et al. 2013) found that prenatal exposure to DES was significantly associated to neoplasms including vaginal adenosis and clear cell adenocarcinoma on the walls of the vagina. Also, a couple of studies have demonstrated that DES can inhibit vaginal stroma which can result in insistent downregulation of transcription factors (Katoh et al. 2013; Laronda et al. 2013; Nakamura et al. 2012), largely affecting reproduction. A study conducted in the USA found that women exposed to organochlorides experienced a lengthened time they were expecting to give birth (Buck Louis et al. 2013).

Also, one animal study conducted in the USA found that maternal Wistar rats' exposure to triclosan significantly delayed vaginal opening (VO) of the offspring, decreased pup weight, and live birth index. Velez et al. (2015) also found that among 2001 women, who were exposed to bisphenol, triclosan, and phthalates, those within their first trimester in their pregnancy were more likely to experience fertility decline in their later years due to the triclosan effect, no significant association between fertility and bisphenol and phthalates was found. This study finding was consistent with what (Weuve et al. 2010) found, that time to exposure was a significant moderator of the exposure risk level. Yoshida et al. (2011) also found that female mice exposed to DES $(150-1500 \mu \mathrm{g} / \mathrm{kg})$ experienced a damaged morphological structure of their genital tract. Couple of studies (Bhattacharya and Munshi 2021; Patisaul 2021) from different countries have also attempted to evaluate the impact of EDCs on the reproductive health of women. However, surprisingly, we did not find any study from Africa that assessed the impact of EDCs on the reproductive health of women.

\section{Impact of EDCs on ovarian health and fertility}

There have been attempts to investigate EDC's impact on ovarian development and health through a couple of animal and human studies. An animal study by Rivera et al. (2011) involving sheep found that reduced doses of BPA showed evidence in the upturn of the ovarian follicle and altered steroidogenesis of the ovary. BPA is environmentally ubiquitous since they are common plasticizers used for making various PCPs including dental sealants and baby bottles (Jagne et al. 2016; J. Liu et al. 2018; Maffini et al. 2006). Therefore, they have been found in various parts of the human system including breast milk, urine, blood, sweats, umbilical cords, placenta, serums, and even amnion fluids, making their reproductive health impact enormous (Patel et al. 2015). One study involving female monkeys found that exposure to higher BPA amounts affected ovarian meiosis, caused synaptic changes, and interrupted the recombination of homologous chromosomes (Hunt et al. 2012). Some studies also found that sheep and rats in their gestational times exposed to certain EDCs experienced anomalies in their ovarian development. For example, a higher intake of BPA was associated with increased cystification of the follicles, decreased volume of the corpus luteum, and decreased amount of the antral follicles (Rodríguez et al. 2010; Delclos et al. 2014). Petro et al. (2012) also found the association between increased human bodily contaminations of bisphenol and ovarian declined in follicle liquid and reduced rate of fertilization. They also found that this chemical destroyed the necessary conditions for oocyte development in women. Others have associated BPA intake with premature ovarian failure, estrous cycle disruption, and disturbances in steroidogenesis (Fernandez et al. 2010; Nah et al. 2011).

While there are scarce studies interrogating the impact of phthalates, pesticides, and other EDCs on pre and postnatal development of the ovary, a minimal number of animal studies have provided valuable consistent insight. A study by Chen et al. (2012) found that postnatal exposure of human ovaries to metabolites of phthalates such as benzyl butyl phthalates was a great risk factor for the development of granulosa cell apoptosis. A couple of pesticides that are ubiquitous in our environment including endosulfan, malathion, chlorpyriphos, and cypermethrin are also noted to cause postnatal ovarian anomalies including declined follicle counts and heightened cases of follicular atresia (Koc et al. 2009; Nandi et al. 2011). Methoxychlor (MXC) which is commonly used as pesticide in agriculture has also been noted to cause serious ovarian problems such as folliculogenesis disturbance. Even though these have been banned in some advanced countries, many less developed countries including those in Africa are still using them as pesticides. For example, about $35 \%$ of agricultural produce contains some extracts of MXC (Krol et al. 2000), they have also been found in well water and soils (Patel et al. 2015), making their reproductive impact noticeable. For instance, some researchers found that exposure to MXC $(1-100 \mathrm{lg} / \mathrm{ml})$ in vitro inhibited the development of antral follicles through mechanisms such as the reduction in the expression of the G1-S phase cycle moderators including the cyclin D2 and cyclin-dependent kinase 4 (Gupta et al. 2009; Miller et al. 2005). Some other studies also showed that MXC is a potential chemical that inhibits ovarian steroidogenesis. For instance, exposure to $1-100 \mathrm{lg} / \mathrm{ml}$ was noted to inhibit the development of estradiol, androstenedione, and testosterone in mouse antral follicles (Basavarajappa et al. 2011). MXC impact on steroid levels may result from its ability to stop the expression of crucial factors in the estradiol synthesis pathway (including 3b-hydroxysteroid dehydrogenase-1, 17b-hydroxysteroid dehydrogenase-1, etc.) (Basavarajappa et al. 2011). Examples of 
other EDCs noted to cause elevated atretic follicles and peroxidative disruption are endosulfan and Malathion (Koc et al. 2009). Crucially, the follicular impact of these EDCs can result in either temporary or permanent infertility in women depending on whether the said chemical targeted the mature or the immature follicle (Patel et al. 2015; Rattan and Flaws 2019). For example, if the endocrine disruptor attacks the mature follicles, they can be removed to allow new ones to develop, thus restoring the fertility, however, when it targets the immature follicles, it damages them completely, which can lead to permanent infertility. Given that millions of women globally experience infertility due to increased EDCs-based PCPs consumption, it has become a significant public health challenge.

\section{Considering the spatial disparity in the research effort}

EDCs induced sexual malfunctioning may vary across different locations and between individuals depending on; race, education, income, geography, and other related sociocultural attributes of people. But given that, most areas still have a dearth of research investigating the health risk of EDCs exposure; disease burden will disproportionately differ across different spatial settings. For example, only 2 studies investigating the fate of EDCs were found in South Africa (Farounbi 2020; Olaniyan and Okoh 2020), and one (Manaca et al. 2011) from Mozambique. Even with that, none of these studies investigated, primarily, the impact of these EDCs on reproduction. From Fig. 5, it is obvious that there is virtually no study in Africa investigating EDCs exposure and reproductive health. However, on grounds that, in Africa and some parts of Asia, environmental pollution has already exposed millions of people to environmental toxins, imposition of endocrine disruptive chemicals resulting from increased use of personal care products coupled with lack of research and remediation strategies may worsen the reproductive health condition of millions of people.

Higher levels of triclosan and 4-tert-Octylphenol have been discovered in River Buffalos in South Africa (Olaniyan and Okoh 2020). Similarly, appreciable amounts of 4-nonylphenol, 2, 4-dichlorophenol, estrone, 17 $\beta$-estradiol, bisphenol A, 4-tertoctylphenol, triclosan,

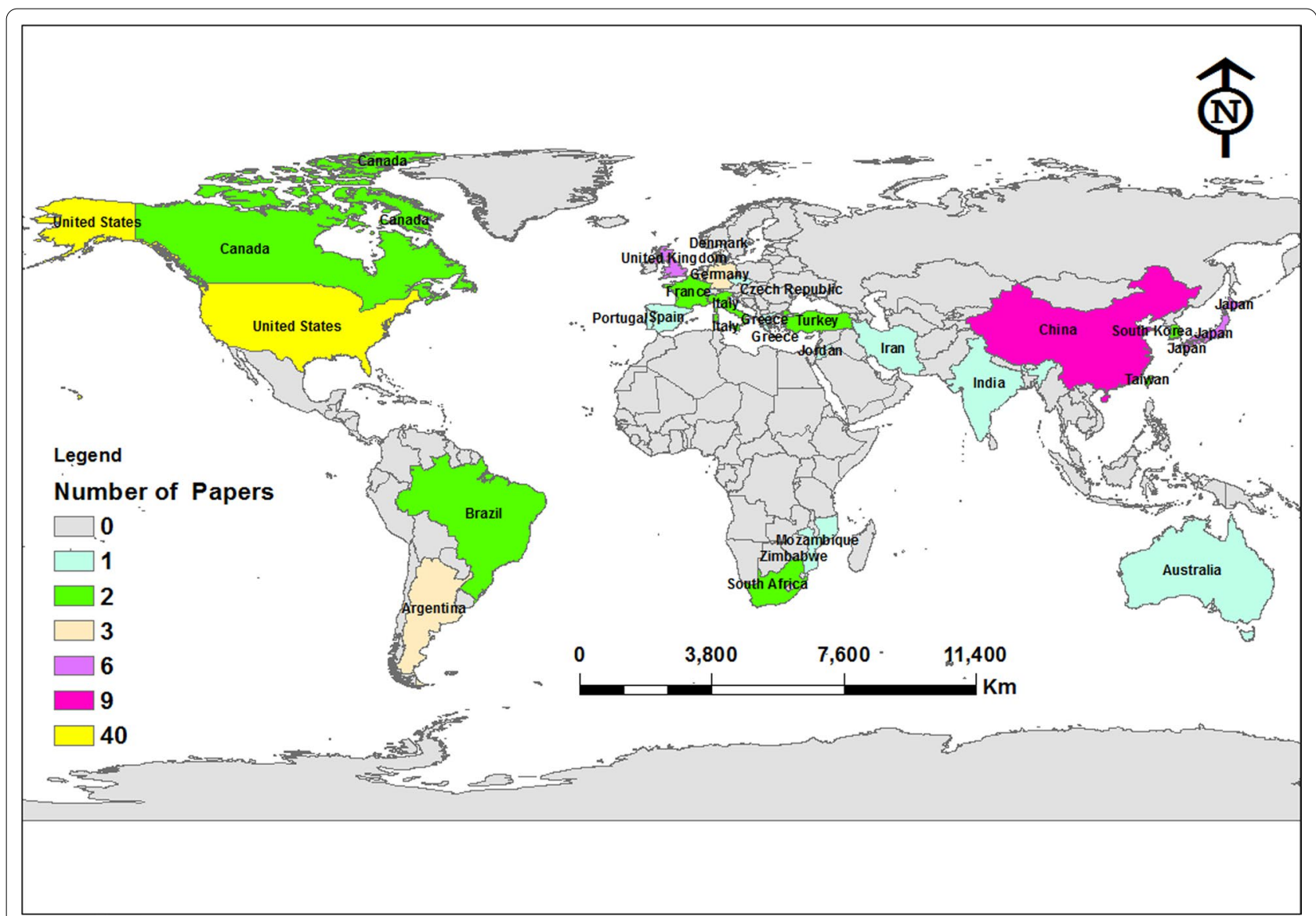

Fig. 5 Spatial distribution of researches conducted on EDCs abundance, exposure, and impact on reproductive health 
atrazine, imidazole, and 1, 2, 4-triazole have been found in treatment plants and river bodies in the eastern cape province of South Africa (Farounbi and Ngqwala 2020). While people's exposure to these EDCs is certain, how exactly they meddle with reproduction across different people in Africa is unknown. Further, on racial grounds, some researchers found that the concentration of butyl paraben and propyl paraben was higher in non-Whitemen than Whitemen in America $(p<0.05)$ (James-Todd et al. 2016). It is therefore probable that there exist sharp differences in EDCs exposure risk between different people in different geographical locations and with diverse sociocultural, economic, and biochemical backgrounds. This means that generalization of study results in terms of exposure magnitude and reproductive effects may not be enough to reveal holistic reality. This, therefore, warrants urgent research in Africa and other less developed countries to uncover these dynamics.

\section{The way forward}

So far, it is apparent that thousands of endocrine disruptors exist in our environment today (as exemplified in Table 1), and that their impact on reproductive health is pronounced. On grounds that these chemicals: their sources, exposure pathways, and impact, are further complicated by socio-spatial heterogeneity, we suggest that:

- During exposure assessment, researchers should factor in multiple factors such as differential socioeconomic statuses, races, the physical environment itself, and gender and education level among the people. To help understand how a combination of these factors will drive PCPs use and exposure risk among different people.

- Researchers consider how different people respond to the reproductive impact of different EDCs. Also, time to exposure, especially among pregnant women, should be considered during impact assessment.

- To practitioners, before any consumable is released into the market for sales and consumption, a detailed examination of the chemical ingredients should be examined; in light of the magnitude of impact it will have on the people before such product is approved. This suggestion is especially useful for countries in less developed countries where the use, exposure, and impact of EDCs-based products are largely under-researched.

- Finally, none of the studies reviewed hinted at public awareness of these chemicals about their sources, routes of exposure, and reproductive impacts. It is therefore suggested that researchers and practitioners design programs that raise public awareness.
Special attention should be given to places where the illiteracy level is quite high, with less governmental effort to undertake quality control on consumables in the markets.

\section{Conclusions}

Man-made chemicals are now part of our everyday lives due to their widespread uses; as a result, they can be originated from multiple sources. Given that these chemicals can inhibit reproduction in both men and women, it is important we pay key attention to them. Bisphenol, Dioxins, Methoxychlor, and Phthalates are key EDCs affecting reproductive health in men and women, with multi- and intergenerational effects. The concentration of these chemicals in humans and their impact will vary with space and among people. However, there is a dearth of studies in many countries coupled with widespread unawareness among the general public, especially many countries in Africa and Asia concerning the abundance and lethality of these EDCs. As a result, it is suggested that more research on this theme must be funded in countries with an acute shortage of similar studies. And that in providing effective evidence, multitudes of factors (including economics, sociocultural, and physical environmental) should be considered for a comprehensive assessment. Further, we suggest that researchers should collaborate with practitioners and policymakers to design programs that create more awareness among the general public.

\section{Abbreviations}

EDCs: Endocrine disruptive chemicals; PCPs: Personal care products; ACOG: American Congress of Obstetrics and Gynaecology; FIGO: Internal Federation on Obstetrics and Gynaecology; NHANES: National Health and Nutrition Examination Survey; MXC: Methoxychlor; BPA: Bisphenol A; MEHP: Mono(2-ethylhexyl) phthalate); MEHHP: (Mono-(2-ethyl-5-hydrohexyl) phthalate); EOP: (Mono- (2-ethyl-oxohexyl) phthalate); MEPs: Methyl ethyl phthalates; MBP: Methyl butyl paraben; MiBP: Methyl-iso-butyl paraben; MMP: Monomethyl phthalate; MEHP: Mono-ethyl-hexyl phthalate; MEHHP: Mono-(2-ethyl5-oxy hexyl) phthalate)); MECPP: (Mono-(2-ethyl carboxy-pentyl)phthalate); MCMHP: (Mono-(2-carboxy-methyl-hexyl) phthalate; MP: Methyl paraben; EP: Ethyl paraben; PP: Propyl paraben; BP: Butyl paraben; CDC: Centers for disease control and prevention; UV: Ultraviolet radiation; 1 1 1 DDE: Dichlorodiphenyldichloroethylene; TCDD: 2, 3, 7, 8-Tetrachlorodbenzo-p-dioxin; DEHP: Di (2-ethylhexyl) phthalate; AGD: Anogenital distance; DNA: Deoxyribonucleic acid; MnBP: Mono-n-butyl phthalate; MEP: Monomethyl phthalate; DDT: Dicholorodiethyltricholoroethene; PVC: Polyvinyl chlorides; PRISMA: Preferred reporting items for systematic reviews and meta-analyses; CIR: Consumer ingredient review.

\section{Acknowledgements}

We thank the anonymous reviewers. Their constructive suggestions helped to improve the paper.

\section{Authors' contributions}

MA conceptualized the study and wrote the initial version of the manuscript. JO collated data and revised. DK collated data and analyzed the results. TAA 
wrote portions of the manuscript. RMG reviewed and revised the manuscript. All authors read and approved the final version of the manuscript.

\section{Funding}

No funding was received.

\section{Availability of data and materials}

Not applicable.

\section{Declarations}

Ethics approval and consent to participate

Not applicable.

\section{Consent for publication}

Not applicable.

\section{Competing interests}

The authors declare that they have no competing interest.

\section{Author details}

${ }^{1}$ Department of Geography and Rural Development, Kwame Nkrumah University of Science and Technology, Kumasi, Ghana. ${ }^{2}$ Department of Planning, Kwame Nkrumah University of Science and Technology, Kumasi, Ghana. ${ }^{3}$ African Population and Health Research Center (APHRC), Nairobi, Kenya.

Received: 29 December 2021 Accepted: 14 February 2022 Published online: 07 March 2022

\section{References}

Ababneh FA, Al-Momani IF (2018) Assessments of toxic heavy metals contamination in cosmetic products. Environ Forensics 19(2):134-142

Abbasi Y, Mannaerts CM (2020) Exploring the environmental exposure to Methoxychlor, a-HCH and endosulfan-sulfate residues in lake Naivasha (Kenya) using a multimedia fate modeling approach. Int J Environ Res Public Health 17(8):2727

Alwis ID, Maroni DM, Hendry IR, Roy SK, May JV, Leavitt WW, Hendry WJ (2011) Neonatal diethylstilbestrol exposure disrupts female reproductive tract structure/function via both direct and indirect mechanisms in the hamster. Reprod Toxicol 32(4):472-483

Aso S, Ehara H, Miyata K, Hosyuyama S, Shiraishi K, Umano T, Minobe Y (2005). A two-generation reproductive toxicity study of butyl benzyl phthalate in rats. J Toxicol Sci, 30(Special), S39-58.

Aydemir D, Oztasci B, Barlas N, Ulusu NN (2020) In fluence of the butylparaben administration on the oxidative stress metabolism of liver, kidney and spleen. Turk J Biochem 45(6):689-694

Babalola AS, Idowu OA, Ademolu KO, Olukunle J, Rahman SA (2020) Antiplasmodial activities and abortifacient properties of three commonly used African indigenous anti-malarial plants in Plasmodium berghei infected pregnant mice: implication for maternal and fetal health. Bull Natl Res Centre. https://doi.org/10.1186/s42269-020-00399-5

Baird DD, Newbold R (2005) Prenatal diethylstilbestrol (DES) exposure is associated with uterine leiomyoma development. Reprod Toxicol 20(1):81-84

Basavarajappa MS, Craig ZR, Hernández-Ochoa I, Paulose T, Leslie TC, Flaws JA (2011) Methoxychlor reduces estradiol levels by altering steroidogenesis and metabolism in mouse antral follicles in vitro. Toxicol Appl Pharmacol 253(3):161-169

Bellavia A, Mínguez-Alarcón L, Ford JB, Keller M, Petrozza J, Williams PL, Hauser $R$, James-Todd T (2019) Association of self-reported personal care product use with blood glucose levels measured during pregnancy among women from a fertility clinic. Sci Total Environ 695:133855. https://doi. org/10.1016/j.scitotenv.2019.133855

Bethea TN, Wesselink AK, Weuve J, McClean MD, Hauser R, Williams PL, Ye X, Calafat AM, Baird DD, Wise LA (2020) Correlates of exposure to phenols, parabens, and triclocarban in the Study of Environment, Lifestyle and Fibroids. J Eposure Sci Environ Epidemiol 30(1):117-136

Bhattacharya S, Munshi C (2021) Endocrine disruptors in freshwater: impact on teleost reproduction. Proc Zool Soc 74(4):369-377
Blinkhorn A, Bartold PM, Cullinan MP, Madden TE, Marshall RI, Raphael SL, Seymour GJ (2009) Is there a role for triclosan/copolymer toothpaste in the management of periodontal disease? Br Dent J 207(3):117-125

Bonde JP, Flachs EM, Rimborg S, Glazer CH, Giwercman A, Ramlau-Hansen CH, Hougaard KS, Høyer BB, Hærvig KK, Petersen SB (2017) The epidemiologic evidence linking prenatal and postnatal exposure to endocrine disrupting chemicals with male reproductive disorders: a systematic review and meta-analysis. Hum Reprod Update 23(1):104-125

Bu Z, Wang J, Yu W, Li B (2018) Dermal exposure to phthalates in home environment: Handwipes, influencing factors and implications. Build Environ 133:1-7

Buah-Kwofie A, Humphries MS (2021) Organochlorine pesticide accumulation in fish and catchment sediments of Lake St Lucia: Risks for Africa's largest estuary. Chemosphere 274:129712

Buck Louis GM, Peterson CM, Chen Z, Croughan M, Sundaram R, Stanford J, Varner MW, Kennedy A, Giudice L, Fujimoto VY, Sun L, Wang L, Guo Y, Kannan K (2013) Bisphenol A and phthalates and endometriosis: the endometriosis: Natural History, Diagnosis and Outcomes Study. Fertil Steril 100(1):162. https://doi.org/10.1016/j.fertnstert.2013.03.026

Calafat AM, Ye X, Wong LY, Bishop AM, Needham LL (2010) Urinary concentrations of four parabens in the U.S. population: NHANES 2005-2006. Environ Health Perspect 118(5):679-685. https://doi.org/10.1289/ehp. 0901560

Chen H-S, Chiang P-H, Wang Y-C, Kao M-C, Shieh T-H, Tsai C-F, Tsai E-M (2012) Benzyl butyl phthalate induces necrosis by AhR mediation of CYP1B1 expression in human granulosa cells. Reprod Toxicol 33(1):67-75

Cirillo PM, LaMerrill MA, Krigbaum NY, Cohn BA (2021). Grandmaternal perinatal serum DDT in relation to granddaughter early menarche and adult obesity: three generations in the child health and development studies cohort. Cancer Epidemiol Prevent Biomark

Costa EMF, Spritzer PM, Hohl A, Bachega TASS (2014) Effects of endocrine disruptors in the development of the female reproductive tract. Arquivos Brasileiros De Endocrinol Metabol 58(2):153-161. https://doi.org/10. 1590/0004-2730000003031

Cullinan MP, Palmer JE, Carle AD, West MJ, Seymour GJ (2012) Long term use of triclosan toothpaste and thyroid function. Sci Total Environ 416:75-79

David M, Alessandro L, Jennifer T, Douglas G, The PRISMA Group (2009) The, preferred reporting items for systematic reviews and meta-analyses: the PRISMA statement. PLoS Med. 6(7):e1000097. https://doi.org/10.1371/ journal.pmed.1000097

D'Aloisio AA, Baird DD, DeRoo LA, Sandler DP (2012) Early-life exposures and early-onset uterine leiomyomata in black women in the Sister Study. Environ Health Perspect 120(3):406-412

Dewalque L, Charlier C, Pirard C (2014) Estimated daily intake and cumulative risk assessment of phthalate diesters in a Belgian general population. Toxicol Lett 231(2):161-168

Di Renzo GC, Conry JA, Blake J, DeFrancesco MS, DeNicola N, Martin JNJ, McCue KA, Richmond D, Shah A, Sutton P, WoodruffTJ, van der Poel SZ, Giudice LC (2015) International federation of gynecology and obstetrics opinion on reproductive health impacts of exposure to toxic environmental chemicals. Int J Gynaecol Obstet 131(3):219-225. https://doi. org/10.1016/j.jjgo.2015.09.002

Dieckmann WJ, Davis ME, Rynkiewicz LM, Pottinger RE (1953) Does the administration of diethylstilbestrol during pregnancy have therapeutic value? Am J Obstet Gynecol 66(5):1062-1081

Dodge LE, Williams PL, Williams MA, Missmer SA, Toth TL, Calafat AM, Hauser R (2015) Paternal urinary concentrations of parabens and other phenols in relation to reproductive outcomes among couples from a fertility clinic. Environ Health Perspect 123(7):665-671. https://doi.org/10.1289/ ehp. 1408605

Dutta S, Haggerty DK, Rappolee DA, Ruden DM (2020) Phthalate exposure and long-term epigenomic consequences: a review. Front Genet 11 (May):1-27. https://doi.org/10.3389/fgene.2020.00405

Elmore SE, Cano-Sancho G, La Merrill MA (2020) Disruption of normal adipocyte development and function by methyl-and propyl-paraben exposure. Toxicol Lett 334:27-35

Farounbi Al, Ngqwala NP (2020) Occurrence of selected endocrine disrupting compounds in the Eastern Cape province of South Africa. Environ Sci Pollut Res Int. 27(14):17268-17279. https://doi.org/10.1007/ s11356-020-08082-y 
Fiandanese N, Borromeo V, Berrini A, Fischer B, Schaedlich K, Schmidt JS, Secchi C, Pocar P (2016) Maternal exposure to a mixture of di (2-ethylhexyl) phthalate (DEHP) and polychlorinated biphenyls (PCBs) causes reproductive dysfunction in adult male mouse offspring. Reprod Toxicol 65:123-132

Foster WG, Maharaj-Briceño S, Cyr DG (2010) Dioxin-induced changes in epididymal sperm count and spermatogenesis. Environ Health Perspect 118(4):458-464

Frankel TE, Bohannon ME, Frankel JS (2020) Assessing the impacts of methoxychlor exposure on the viability, reproduction, and locomotor behavior of the seminole ramshorn snail (Planorbella duryi). Environ Toxicol Chem 39(1):220-228

Garlantézec R, Warembourg C, Monfort C, Labat L, Pulkkinen J, Bonvallot N, Multigner L, Chevrier C, Cordier S (2013) Urinary glycol ether metabolites in women and time to pregnancy: The PELAGIE cohort. Environ Health Perspect 121(10):1167-1173. https://doi.org/10.1289/ehp.12061 03

Gravel S, Lavoué J, Bakhiyi B, Lavoie J, Roberge B, Patry L, Bouchard MF, Verner MA, Zayed J, Labrèche F (2020) Multi-exposures to suspected endocrine disruptors in electronic waste recycling workers: Associations with thyroid and reproductive hormones. Int J Hyg Environ Health. 225:113445. https://doi.org/10.1016/j.jijheh.2019.113445

Gupta RK, Meachum S, Hernández-Ochoa I, Peretz J, Yao HH, Flaws JA (2009) Methoxychlor inhibits growth of antral follicles by altering cell cycle regulators. Toxicol Appl Pharmacol 240(1):1-7

Hammel SC, Levasseur JL, Hoffman K, Phillips AL, Lorenzo AM, Calafat AM, Webster TF, Stapleton HM, States U (2019) Children's exposure to phthalates and non-phthalate plasticizers in the home : the TESIE study. Environ Int 132(June):105061. https://doi.org/10.1016/j.envint.2019. 105061

Hannas BR, Furr J, Lambright CS, Wilson VS, Foster PMD, Gray LE Jr (2011) Dipentyl phthalate dosing during sexual differentiation disrupts fetal testis function and postnatal development of the male SpragueDawley rat with greater relative potency than other phthalates. Toxicol Sci 120(1):184-193

Hannon PR, Flaws JA (2015). The effects of phthalates on the ovary. Frontiers in Endocrinology, 6(FEB), 1-20. https://doi.org/10.3389/fendo.2015.00008

Hardon A, Idrus NI, Hymans TD (2013) Chemical sexualities: the use of pharmaceutical and cosmetic products by youth in South Sulawesi Indonesia. Reprod Health Matters. 21(41):214-24. https://doi.org/10.1016/S09688080(13)41709-3

Harris RM, Waring RH (2012) Diethylstilboestrol—a long-term legacy. Maturitas 72(2):108-112

Hartmann C, Uhl M, Weiss S, Koch HM, Scharf S, König J (2015) Human biomonitoring of phthalate exposure in Austrian children and adults and cumulative risk assessment. Int J Hyg Environ Health 218(5):489-499

Herbst AL (1976) Summary of the changes in the human female genital tract as a consequence of maternal diethylstilbestrol therapy. J Toxicol Environ Health. 1:13-20

Herbst AL, Ulfelder H, Poskanzer DC (1971) Adenocarcinoma of the vagina. Association of maternal stilbestrol therapy with tumor appearance in young women. N Engl J Med. 284(15):878-81. https://doi.org/10.1056/ NEJM197104222841604

Honda M, Kannan K (2018) Biomonitoring of chlorophenols in human urine from several Asian countries, Greece and the United States. Environ Pollut 232:487-493. https://doi.org/10.1016/j.envpol.2017.09.073

Hu W, Dong T, Wang L, Guan Q, Song L, Chen D, Zhou Z, Chen M, Xia Y, Wang $X$ (2017) Obesity aggravates toxic effect of BPA on spermatogenesis. Environ Int 105:56-65

Hunt PA, Lawson C, Gieske M, Murdoch B, Smith H, Marre A, Hassold T, VandeVoort CA (2012) Bisphenol A alters early oogenesis and follicle formation in the fetal ovary of the rhesus monkey. Proc Natl Acad Sci 109(43):17525-17530

Hutin D, Long AS, Sugamori K, Shao P, Singh SK, Rasmussen M, Olafsen NE, Pettersen S, Grimaldi G, Grant DM, Matthews J (2021) 2,3,7,8-Tetrachlorodibenzo-p-Dioxin (TCDD)-Inducible Poly-ADP-Ribose Polymerase (TIPARP/PARP7) Catalytic Mutant Mice (TiparpH532A) Exhibit Increased Sensitivity to TCDD-Induced Hepatotoxicity and Lethality. Toxicol Sci 183(1):154-169. https://doi.org/10.1093/toxsci/kfab075

Inhorn MC, Patrizio P (2015) Infertility around the globe: new thinking on gender, reproductive technologies and global movements in the $21 \mathrm{st}$ century. Hum Reprod Update 21(4):411-426. https://doi.org/10.1093/ humupd/dmv016

Iribarne-Durán LM, Domingo-Piñar S, Peinado FM, Vela-Soria F, Jiménez-Díaz I, Barranco E, Olea N, Freire C, Artacho-Cordón F, Ocón-Hernández O (2020) Menstrual blood concentrations of parabens and benzophenones and related factors in a sample of Spanish women: an exploratory study. Environ Res 183(January):109228. https://doi.org/10.1016/j. envres.2020.109228

Jagne J, White D, Jefferson F (2016) Endocrine-disrupting chemicals: adverse effects of bisphenol a and parabens to women's health. Water Air Soil Pollut. https://doi.org/10.1007/s11270-016-2785-3

James-Todd TM, Chiu YH, Zota AR (2016) Racial/ethnic disparities in environmental endocrine disrupting chemicals and women's reproductive health outcomes: epidemiological examples across the life course. Curr Epidemiol Rep 3(2):161-180

Kang KS, Che JH, Ryu DY, Kim TW, Li GX, Lee YS (2002) Decreased sperm number and motile activity on the F1 offspring maternally exposed to butyl p-hydroxybenzoic acid (butyl paraben). J Vet Med Sci 64(3):227-235. https://doi.org/10.1292/jvms.64.227

Katoh T, Hayashi S, Iguchi T, Sato T (2013) Epithelial-stromal interactions in the mouse vagina exposed neonatally to diethylstilbestrol. In Vivo 27(3):333-337

Khalili F, Mahvi AH, Nasseri S, Yunesian M, Yaseri M, Djahed B (2019) Health risk assessment of dermal exposure to heavy metals content of chemical hair dyes. Iran J Public Health 48(5):902

Khasin LG, Della Rosa J, Petersen N, Moeller J, Kriegsfeld LJ, Lishko PV (2020) The impact of Di-2-ethylhexyl phthalate on sperm fertility. Front Cell Dev Biol 8(June):1-14. https://doi.org/10.3389/fcell.2020.00426

Koc ND, Kayhan FE, Sesal C, Muslu MN (2009) Dose-dependent effects of endosulfan and Malathion on adult Wistar albino rat ovaries. Pak J Biol Sci 12(6):498

Krol WJ, Arsenault TL, Pylypiw HM, Incorvia Mattina MJ (2000) Reduction of pesticide residues on produce by rinsing. J Agric Food Chem 48(10):4666-4670

Kurnik K, Treder K, Twarużek M, Grajewski J, Tretyn A, Tyburski J (2018) Potato pulp as the peroxidase source for 2, 4-dichlorophenol removal. Waste and Biomass Valorization 9(6):1061-1071

Lang C, Fisher M, Neisa A, Mackinnon L, Kuchta S, Macpherson S, Probert A, Arbuckle TE (2016) Personal care product use in pregnancy and the postpartum period: Implications for exposure assessment. Int J Environ Res Public Health. https://doi.org/10.3390/ijerph13010105

Laronda MM, Unno K, Ishi K, Serna VA, Butler LM, Mills AA, Orvis GD, Behringer RR, Deng C, Sinha S (2013) Diethylstilbestrol induces vaginal adenosis by disrupting SMAD/RUNX1-mediated cell fate decision in the Müllerian duct epithelium. Dev Biol 381(1):5-16

Li YF, Canário AVM, Power DM, Campinho MA (2019) loxynil and diethylstilbestrol disrupt vascular and heart development in zebrafish. Environ Int 124:511-520

Liu W, Chen Q, He N, Sun K, Sun D, Wu X, Duan S (2018) Removal and biodegradation of $17 \beta$-estradiol and diethylstilbestrol by the freshwater microalgae Raphidocelis subcapitata. Int J Environ Res Public Health 15(3):452

Liu J, Wattar N, Field CJ, Dinu I, Dewey D, Martin JW, Team Ap S (2018) Exposure and dietary sources of bisphenol A (BPA) and BPA-alternatives among mothers in the APrON cohort study. Environ Int 119:319-326

Maffini MV, Rubin BS, Sonnenschein C, Soto AM (2006) Endocrine disruptors and reproductive health: The case of bisphenol-A. Mol Cell Endocrinol 254-255:179-186. https://doi.org/10.1016/j.mce.2006.04.033

Mahalingaiah S, Hart JE, Wise LA, Terry KL, Boynton-Jarrett R, Missmer SA (2014) Prenatal diethylstilbestrol exposure and risk of uterine leiomyomata in the Nurses' Health Study II. Am J Epidemiol 179(2):186-191

Mai X, Dong Y, Xiang L, Er Z (2020) Maternal exposure to 2, 3, 7, 8-tetrachlorodibenzo-p-dioxin suppresses male reproductive functions in their adulthood. Hum Exp Toxicol 39(7):890-905. https://doi.org/10.1177/ 0960327120903489

Manaca MN, Grimalt JO, Sunyer J, Mandomando I, Gonzalez R, Sacarlal J, Dobaño C, Alonso PL, Menendez C (2011) Concentration of DDT compounds in breast milk from African women (Manhiça, Mozambique) at the early stages of domestic indoor spraying with this insecticide. Chemosphere 85(3):307-314. https://doi.org/10.1016/j. chemosphere.2011.06.015 
Mansouri A, Cregut M, Abbes C, Durand MJ, Landoulsi A, Thouand G (2017) The environmental issues of DDT pollution and bioremediation: a multidisciplinary review. Appl Biochem Biotechnol 181(1):309-339

Meeker JD, Yang T, Ye X, Calafat AM, Hauser R (2011) Urinary concentrations of parabens and serum hormone levels, semen quality parameters, and sperm DNA damage. Environ Health Perspect 119(2):252-257. https://doi.org/10.1289/ehp.1002238

Miller KP, Gupta RK, Greenfeld CR, Babus JK, Flaws JA (2005) Methoxychlor directly affects ovarian antral follicle growth and atresia through $\mathrm{BCl}-$ 2-and Bax-mediated pathways. Toxicol Sci 88(1):213-221

Mínguez-Alarcón L, Chiu YH, Nassan FL, Williams PL, Petrozza J, Ford JB, Calafat AM, Hauser R, Chavarro JE (2019) Urinary concentrations of benzophenone- 3 and reproductive outcomes among women undergoing infertility treatment with assisted reproductive technologies. Sci Total Environ 678:390-398. https://doi.org/10.1016/j.scitotenv. 2019.04.452

Moos RK, Apel P, Schröter-Kermani C, Kolossa-Gehring M, Brüning T, Koch HM (2017) Daily intake and hazard index of parabens based upon 24 h urine samples of the German Environmental Specimen Bank from 1995 to 2012. J Eposure Sci Environ Epidemiol 27(6):591-600. https:// doi.org/10.1038/jes.2016.65

Mulla H, Yakkundi S, McElnay J, Lutsar I, Metsvaht T, Varendi H, Nellis G, Nunn A, Duncan J, Pandya H, Turner M (2015) An observational study of blood concentrations and kinetics of methyl- and propyl-parabens in neonates. Pharm Res 32(3):1084-1093. https://doi.org/10.1007/ s11095-014-1520-2

Nah WH, Park MJ, Gye MC (2011) Effects of early prepubertal exposure to bisphenol A on the onset of puberty, ovarian weights, and estrous cycle in female mice. Clin Exp Reprod Med 38(2):75

Nakamura T, Miyagawa S, Katsu Y, Watanabe H, Mizutani T, Sato T, Morohashi Kl, Takeuchi T, Iguchi T, Ohta Y (2012) Wnt family genes and their modulation in the ovary-independent and persistent vaginal epithelial cell proliferation and keratinization induced by neonatal diethylstilbestrol exposure in mice. Toxicology 296(1-3):13-19

Nandi S, Gupta PSP, Roy SC, Selvaraju S, Ravindra JP (2011) Chlorpyrifos and endosulfan affect buffalo oocyte maturation, fertilization, and embryo development in vitro directly and through cumulus cells. Environ Toxicol 26(1):57-67

Nassan FL, Coull BA, Gaskins AJ, Williams MA, Skakkebaek NE, Ford JB, Ye X, Calafat AM, Braun JM, Hauser R (2017) Personal care product use in men and urinary concentrations of select phthalate metabolites and parabens: results from the environment and reproductive health (earth) study. Environ Health Perspect 125(8):1-10. https://doi.org/10. 1289/EHP1374

Neff AM, Flaws JA (2021) The effects of plasticizers on the ovary. Curr Opin Endocrine Metab Res 18:35-47. https://doi.org/10.1016/j.coemr.2021. 01.004

Nyoni-Kachambwa P, Naravage W, James NF, Van der PM (2021) A preliminary study of skin bleaching and factors associated with skin bleaching among women living in Zimbabwe. Afr Health Sci 21(1):132-139. https://doi.org/10.4314/ahs.v21i1.18

Oishi S (2001) Effects of butylparaben on the male reproductive system in rats. Toxicol Ind Health 17(1):31-39. https://doi.org/10.1191/07482 33701 th093oa

Oishi S (2004) Lack of spermatotoxic effects of methyl and ethyl esters of p-hydroxybenzoic acid in rats. Food Chem Toxicol : Int J Publ Brit Indust Biol Res Assoc 42(11):1845-1849. https://doi.org/10.1016/j.fct. 2004.06.015

Olaniyan LWB, Okoh Al (2020). Determination and ecological risk assessment of two endocrine disruptors from River Buffalo, South Africa.

Oyugi AM, Kibet JK, Adongo JO (2021) A review of the health implications of heavy metals and pesticide residues on khat users. Bull Natl Res Centre. https://doi.org/10.1186/s42269-021-00613-y

Patel S, Zhou C, Rattan S, Flaws JA (2015) Effects of endocrine-disrupting chemicals on the ovary. Biol Reprod 93(1):1-9. https://doi.org/10. 1095/biolreprod.115.130336

Patisaul HB (2021) REPRODUCTIVE TOXICOLOGY: Endocrine disruption and reproductive disorders: impacts on sexually dimorphic neuroendocrine pathways. Reprod (Camb, Engl) 162(5):F111-F130
Patisaul HB, Adewale HB (2009) Long-term effects of environmental endocrine disruptors on reproductive physiology and behavior. Front Behav Neurosci. https://doi.org/10.3389/neuro.08.010.2009

Petro EML, Leroy JLMR, Covaci A, Fransen E, De Neubourg D, Dirtu AC, De Pauw I, Bols PEJ (2012) Endocrine-disrupting chemicals in human follicular fluid impair in vitro oocyte developmental competence. Hum Reprod 27(4):1025-1033

Petersen KU, Balkiss AM, Hærvig KK, Peter J, Bonde E, Hougaard KS, Toft G, Ramlau-hansen CH, Tøttenborg SS (2020) A Cross-Sectional Study in Young Danish Men. Toxic Article 8(62):1-13. https://doi.org/10.3390/ toxics8030062

Pirard C, Compere S, Firquet K, Charlier C (2018) International Journal of Hygiene and The current environmental levels of endocrine disruptors (mercury, cadmium, organochlorine pesticides and PCBs) in a Belgian adult population and their predictors of exposure. Int J Hyg Environ Health 221(2):211-222. https://doi.org/10.1016/j.ijheh.2017.10.010

Priskorn L, Nordkap L, Bang AK, Krause M, Holmboe SA, Egeberg Palme DL, Winge SB, Mørup N, Carlsen E, Joensen UN, Blomberg JM, Main KM, Juul A, Skakkebaek NE, Jensen TK, Jørgensen N (2018) Average sperm count remains unchanged despite reduction in maternal smoking: results from a large cross-sectional study with annual investigations over 21 years. Hum Reprod (Oxford, Engl) 33(6):998-1008. https://doi.org/10. 1093/humrep/dey090

Publicover SJ, Giojalas LC, Teves ME, De Oliveira GS, Garcia AA, Barratt CL, Harper CV (2008) Ca2+ signalling in the control of motility and guidance in mammalian sperm. Front Biosci 13:5623-5637

Rattan S, Flaws JA (2019) The epigenetic impacts of endocrine disruptors on female reproduction across generations. Biol Reprod 101(3):635-644. https://doi.org/10.1093/biolre/ioz081

Rehfeld A, Rehfeld A, Egeberg DL, Almstrup K, Petersen JH, Dissing S, Skakkebæk NE (2018) EDC IMPACT: chemical UV filters can affect human sperm function in a progesterone-like manner. Endocr Connect 7:16-25

Rivera OE, Varayoud J, Rodríguez HA, Muñoz-de-Toro M, Luque EH (2011) Neonatal exposure to bisphenol A or diethylstilbestrol alters the ovarian follicular dynamics in the lamb. Reprod Toxicol 32(3):304-312

Rocha BA, Asimakopoulos AG, Barbosa F, Kannan K (2017) Urinary concentrations of 25 phthalate metabolites in Brazilian children and their association with oxidative DNA damage. Sci Total Environ 586:152-162. https:// doi.org/10.1016/j.scitotenv.2017.01.193

Rodríguez PEA, Sanchez MS (2010) Maternal exposure to triclosan impairs thyroid homeostasis and female pubertal development in wistar rat offspring. J Toxicol Environ Health Part A. https://doi.org/10.1080/15287 394.2010.516241

Rodríguez HA, Santambrosio N, Santamaría CG, Muñoz-de-Toro M, Luque EH (2010) Neonatal exposure to bisphenol A reduces the pool of primordial follicles in the rat ovary. Reprod Toxicol 30(4):550-557

Salthammer T (2019). Formaldehyde sources, formaldehyde concentrations and air exchange rates in European housings. In Building and environment, vol 150, pp 219-232. Elsevier Ltd. https://doi.org/10.1016/j.build env.2018.12.042

Sharma A, Mollier J, Brocklesby RWK, Caves C, Jayasena CN, Minhas S (2020) Endocrine-disrupting chemicals and male reproductive health. Reprod Med Biol 19(3):243-253. https://doi.org/10.1002/rmb2.12326

Shen Y, Xu Q, Ren M, Feng X, Cai Y, Gao Y (2013) Measurement of phenolic environmental estrogens in women with uterine leiomyoma. PloS One 8(11):e79838

Shinshi O (2004) Lack of spermatotoxic effects of methyl and ethyl esters of p-hydroxybenzoic acid in rats. Food Chem Toxicol 42(11):1845-1849. https://doi.org/10.1016/.jft.2004.06.015

Signorile PG, Spugnini EP, Mita L, Mellone P, D'Avino A, Bianco M, Diano N, Caputo L, Rea F, Viceconte R (2010) Pre-natal exposure of mice to bisphenol A elicits an endometriosis-like phenotype in female offspring. Gen Comp Endocrinol 168(3):318-325

Signorile PG, Spugnini EP, Citro G, Viceconte R, Vincenzi B, Baldi F, Baldi A (2012) Endocrine disruptors in utero cause ovarian damages linked to endometriosis. Front Biosci (elite Ed) 4:1724-1730

Street ME, Angelini S, Bernasconi S, Burgio E, Cassio A, Catellani C, Cirillo F, Deodati A, Fabbrizi E, Fanos V (2018) Current knowledge on endocrine disrupting chemicals (EDCs) from animal biology to humans, from 
pregnancy to adulthood: highlights from a national Italian meeting. Int J Mol Sci 19(6):1647

Su PH, Huang PC, Lin CY, Ying TH, Chen JY, Wang SL (2012) The effect of in utero exposure to dioxins and polychlorinated biphenyls on reproductive development in eight year-old children. Environ Int 39(1):181-187

Suhaiman L, Altamirano KN, Morales A, Belmonte SA (2021). Different approaches to record human sperm exocytosis. In: Exocytosis and endocytosis, pp 139-168. Springer.

Swan SH, Sathyanarayana S, Barrett ES, Janssen S, Liu F, Nguyen RHN, Redmon JB (2015) First trimester phthalate exposure and anogenital distance in newborns. Hum Reprod 30(4):963-972

Tavares RS, Mansell S, Barratt CLR, Wilson SM, Publicover SJ, Ramalho-Santos J (2013) p, p'-DDE activates CatSper and compromises human sperm function at environmentally relevant concentrations. Hum Reprod 28(12):3167-3177

Troisi R, Hyer M, Hatch EE, Titus-Ernstoff L, Palmer JR, Strohsnitter WC, Herbst AL, Adam E, Hoover RN (2013) Medical conditions among adult offspring prenatally exposed to diethylstilbestrol. Epidemiology, pp. 430-438

Ugelvig Petersen K, Balkiss AM, Hærvig KK, Ellekilde BJP, Hougaard KS, Toft G, Ramlau-Hansen CH, Tøttenborg SS (2020) Use of personal care products and semen quality: a cross-sectional study in young danish men. Toxics. 8(3):62. https://doi.org/10.3390/toxics8030062

Varshavsky JR, Zota AR, WoodruffTJ (2016) A novel method for calculating potency-weighted cumulative phthalates exposure with implications for identifying racial/ethnic disparities among US reproductive-aged women in NHANES 2001-2012. Environ Sci Technol 50(19):10616-10624

Vélez MP, Arbuckle TE, Fraser WD (2015) Female exposure to phenols and phthalates and time to pregnancy: the Maternal- Infant Research on Environmental Chemicals (MIREC) Study. Fertil Steril. 2015(103):1011-20

Vitku J, Heracek J, Sosvorova L, Hampl R, Chlupacova T, Hill M, Sobotka V, Bicikova M, Starka L (2016) Associations of bisphenol A and polychlorinated biphenyls with spermatogenesis and steroidogenesis in two biological fluids from men attending an infertility clinic. Environ Int 89:166-173

Wang Z, Liu H, Liu S (2017) Low-dose bisphenol A exposure: a seemingly instigating carcinogenic effect on breast cancer. Advanced Science 4(2):1600248

Wang Y, Zhu H, Kannan K (2019) A review of biomonitoring of phthalate exposures. Toxics 7(2):1-28. https://doi.org/10.3390/TOXICS7020021

Wang VA, Chu MDT, Chie L, Gaston SA, Jackson CL, Newendorp N, Uretsky E, Dodson RE, Adamkiewicz G, James-Todd T (2021) Acculturation and endocrine disrupting chemical-associated personal care product use among US-based foreign-born Chinese women of reproductive age. J Eposure Sci Environ Epidemiol 31(2):224-232. https://doi.org/10.1038/ s41370-020-00279-0

Wannaz C, Fantke P, Lane J, Jolliet O (2018) Source-to-exposure assessment with the Pangea multi-scale framework-case study in Australia. Environ Sci Process Impacts 20(1):133-144

West ER, Xu M, WoodruffTK, Shea LD (2008) Antiandrogenic properties of parabens. Water 28(30):4439-4448

Weuve J, Hauser R, Calafat AM, Missmer SA, Wise LA (2010) Association of exposure to phthalates with endometriosis and uterine leiomyomata: findings from NHANES, 1999-2004. Environ Health Perspect 118(6):825-832

Woldetsadik D, Simon M P, Knuth D, Hailu H, Gebresilassie A, Dejen A, Düring RA (2021). Exposure to DDT and $\mathrm{HCH}$ congeners and associated potential health risks through khat (Catha edulis) consumption among adults in South Wollo, Ethiopia. Environmental Geochemistry and Health, 1-17.

Yoshida M, Takahashi M, Inoue K, Hayashi S, Maekawa A, Nishikawa A (2011) Delayed adverse effects of neonatal exposure to diethylstilbestrol and their dose dependency in female rats. Toxicol Pathol 39(5):823-834

Yuan W, Chen H, Li J, Zhou S, Zeng Y, Fan J, Zhang Z, Liu J, Cao J, Liu W (2022) TET1 mediated male reproductive toxicity induced by Bisphenol A through Catsper-Ca2+ signaling pathway. Environ Pollut 296:118739. https://doi.org/10.1016/j.envpol.2021.118739

Zhou F, Zhang L, Liu A, Shen Y, Yuan J, Yu X, Feng X, Xu Q, Cheng C (2013) Measurement of phenolic environmental estrogens in human urine samples by HPLC-MS/MS and primary discussion the possible linkage with uterine leiomyoma. J Chromatogr B 938:80-85
Zhu Q, Jia J, Zhang K, Zhang H, Liao C, Jiang G (2019) Phthalate esters in indoor dust from several regions, China and their implications for human exposure. Sci Total Environ 652:1187-1194

Zota AR, Shamasunder B (2017) The environmental injustice of beauty: framing chemical exposures from beauty products as a health disparities concern. Am J Obstet Gynecol 217(4):418.e1-418.e6. https://doi.org/10. 1016/j.ajog.2017.07.020

\section{Publisher's Note}

Springer Nature remains neutral with regard to jurisdictional claims in published maps and institutional affiliations.

\section{Submit your manuscript to a SpringerOpen ${ }^{\circ}$ journal and benefit from:}

- Convenient online submission

- Rigorous peer review

- Open access: articles freely available online

- High visibility within the field

- Retaining the copyright to your article

Submit your next manuscript at $\boldsymbol{\nabla}$ springeropen.com 